\title{
Towards a feminist geopolitics 1
}

\author{
The Inaugural Suzanne Mackenzie Memorial Lecture
}

delivered at the Canadian Association of Ceographers Annual Meeting, Brock University, Ontario, June 2, 2000

JENNIFER HYNDMAN

Department of Geography, Simon Fraser University, Burnaby, British Columbia, Canada V5A IS6 (e-mail: hyndman@sfu.ca)

The intersections and conversations between feminist geography and political geography have been surprisingly few. The notion of a feminist geopolitics remains undeveloped in geography. This paper aims to create a theoretical and practical space in which to articulate a feminist geopolitics. Feminist geopolitics is not an alternative theory of geopolitics, nor the ushering in of a new spatial order, but is an approach to global issues with feminist politics in mind. 'Feminist' in this context refers to analyses and political interventions that address the unequal and often violent relationships among people based on real or perceived differences. Building upon the literature from critical geopolitics, feminist international relations, and transnational feminist studies, I develop a framework for feminist political engagement. The paper interrogates concepts of human security and juxtaposes them with state security, arguing for a more accountable, embodied, and responsive notion of geopolitics. A feminist geopolitics is sought by examining politics at scales other than that of the nation-state; by challenging the public/private divide at a global scale; and by analyzing the politics of mobility for perpetrators of crimes against humanity. As such, feminist geopolitics is a critical approach and a contingent set of political practices operating at scales finer and coarser than the nation-state.

Key words: feminist geography, political geography, mobility, scale
II est surprenant de constater à quel point les échanges entre géographie féministe et géographie politique sont peu nombreux. La notion d'une géopolitique féministe demeure sous-développée en géographie. Ce travail a pour but de créer un espace théorique et pratique favorisant l'émergence d'une géopolitique féministe. La géopolitique féministe n'est pas une théorie alternative de la géopolitique ni l'introduction d'un nouvel ordre spatial mais constitue plutôt une approche politique féministe à la problématique de la mondialisation. Dans un tel contexte, le terme 'féministe' fait référence à des analyses et interventions politiques cherchant $a$ comprendre comment des relations inégales et souvent violentes peuvent être basées sur des différences réelles ou perçues. Minspirant de la littérature critique en géopolitique, des relations internationales féministes, et d'études féministes sur le fait transnational, j'élabore un cadre propice d̀ un engagement politique féministe. Ce travail interroge différents concepts de sécurité humaine et les juxtapose avec ceux de sécurité d'État afin de cheminer vers une notion de géopolitique plus responsable, plus sensible et plus près du corps. Une géopolitique féministe est déployée à travers une analyse de la politique axée sur une échelle autre que f'État-Nation; en questionnant la séparation du public et du privé à une échelle globale; et en analysant le problème de la mobilité pour les individus coupables de crimes contre l'humanité. II s'agit donc d'une approche critique et d'un ensemble contingent de pratiques politiques opérant à des échelles à la fois plus fine et plus grossières que celle de l'État-Nation.

Mots-clés: géographie féministe, géographie politique, mobilité, échelle 
First, I would to thank the nominating committee, Drs. Alan Nash, Damaris Rose, and Fran Klodawsky for putting me on the podium before you today. I am truly honoured to be here, if a bit put out that my efforts to nominate some of you in the audience did not succeed. I would also like to thank the administration at my former university, Arizona State University West, for financial support in bringing me here, and my new colleagues in geography at Simon Fraser University for welcoming me so warmly into the department and back to Canada. Suzanne, herself, was a graduate of geography at Simon Fraser University.

My first encounter with Suzanne was in print, in 1992, while researching a paper on immigrant homeworkers in Vancouver for Gerry Pratt's graduate class in feminist geography (Mackenzie 1989). Suzanne's approach resonated with my own introduction to feminist thought in Scotland and England, if not feminist geography, by Sylvia Walby in the late 1980s. Suzanne's ideas of feminist geography demonstrated a firm commitment to social change that would improve women's lives, and provide "a vision of something better for all of us" (Rose 1999, 407). Her work identifies gender and class as two of the defining analytics of feminist geography. In Suzanne's words, "Feminist geography, like feminism as a whole, is not 'only' about women" (Mackenzie 1999, 419). This declaration proved to hold throughout the 1990 s, as geography expanded its analysis and politics well beyond a 'geography of women' or 'gender and geography' to a thoroughly feminist geography.

Graduate school is often a time of transformation and metamorphosis, and my experience of feminist geography followed a cultural turn in geography as a discipline. A largely Anglo-North American socialist feminist geography did not prove inclusive enough of social relations produced through differences other than gender and class, nor did it prove analytically powerful enough to make sense of disparate power relations in places beyond North America, Scotland, England, New Zealand and Australia. My early research related to industrial homeworkers in the early 1990s, for example, highlighted the inattention on the part of feminist geographers to racialized and immigrant divisions of gendered labour in relation to homework (see Ocran 1997 for positive developments in this area). Multicultural policy in Canada, which has served to efface questions of race and nation, while promoting tolerance of diversity, provides another example of the inextricably racial- ized spaces that immigrant women occupy (Kobayashi 1993). With this cultural turn, feminist geographers have begun to pay serious attention to racism and processes of racialization in their analyses, highlighting the ways in which space and social relations are mutually constituted (Kobayashi and Peake 1994; Ruddick 1996).2 The rise of postcolonial feminisms, and what have been referred to as 'feminist geographies of difference,' marked a cultural turn in geography (Pratt 2000). Relations other than, but including, those of gender and class have been given more credence: nationality, sexuality, race/ethnicity, caste, and ability have all come to the fore of feminist geography.

But it was not only a longer list of differences that rocked the foundations of feminist geography. First, this cultural turn renewed a call for accountability to 'other' peoples and places, beyond the EuroAmerican boundaries and imagination of feminist geography. A move from feminist empiricism to questions of identity and difference ensued (McDowell and Sharp 1997). Second, it served to challenge and refine highly economistic accounts of paid work in both national and global contexts. This turn highlighted cultural as well as economic and political connections among places and peoples. Feminist geography has also begun to link scales - from the foreign-born homeworker in East Vancouver with little English official language competence, who juggles the responsibilities of child care, household work, and garment production in a single space - to the USbased multinational for whom she indirectly works. Scale is critical in structuring political action (Staeheli 1994), and the production of scale is implicated in the production of space (Marston 2000). Third, postcolonial and poststructuralist feminist geographies have provided tools to examine the very ways in which categories such as 'woman', 'immigrant', or 'Kurd' are constructed in subordination (McDowell and Sharp 1997). By no means have the lessons and tools of socialist feminist geography been abandoned. Rather, they have been reworked, strengthened, and redeployed. As Foord et al. $(1999,411)$ put it, "...[I]n remembering Suzanne we are also reminded that what she wanted is not so very different from what many of us still passionately want today: a politics of recognition and a politics of distribution."

A cultural turn in feminist geography is well served by socialist feminisms which ground analyses that may otherwise eclipse the everyday gendered geographies of work on the job and at home (see Klodawsky et al. 1994; 
Hanson and Pratt 1995; Preston 2000). Feminist scholarship in geography has served to mesh these two theoretical approaches by analyzing methodology and the practical problems of conducting research (Moss 1993). Isabel Dyck (1997), for example, has documented the ways in which power differentials are resisted by research subjects. While gender and class relations contribute to such disparities, so too do locations such as immigrant status and cultural identity.

\section{A Political Turn}

The title of my talk builds on both socialist and poststructuralist feminist scholarship in geography and on the work of feminists in political science. I insist on a materialist analysis of social and economic disparities, and the possibility of 'doing something': of normative engagement and action within a given context. My argument also acknowledges the value of interrogating dominant ways and means of producing geographical knowledge - of challenging prevailing geographical stories about place - in order to change them. What I outline today might be called a political turn in feminist geography. Of course, feminist geography is already inherently political in that it advocates change where social relations are inequitable, violent, or exploitative. This political turn, then, calls for a meeting and meshing of the small 'p' political of feminist geography with the larger ' $P$ ' political of political geography.

This proposal is motivated by my work, both as a scholar and as a refugee relief worker for a short period in 1992-93. Much of my scholarship to date has examined patterns of displacement and responses to forced migration (Hyndman 2000), but I feel this approach is incomplete because it focuses less on the power relations that force people from their homes than the geographical outcomes of such violence. Having witnessed the very visceral pain of people out of place and analyzed the international processes and programs invoked to alleviate such suffering, I aim to link scales and analyze the forces that give rise to such human suffering in order to develop a more accountable, embodied, and responsive notion of geopolitics, a feminist geopolitics.

While feminist geographies of difference have proliferated since the late 1980s, the idea of a feminist political geography broadly speaking, or a feminist notion of geopolitics on a global scale, have remained at best an imagined geography, marginal within both feminist and political geography. Ten years ago Linda Peake and Eleonore Kofman published, "Into the 1990s: a gendered agenda for political geography" in Political Geography. At that time, these authors lamented the lack of a feminist analysis within political geography and proceeded to showcase the work of feminists who did 'political' work. They (Kofman and Peake 1990, 315) defined politics as "an activity relevant to all spheres of public and private life," and yet, by example, such a definition was not shared by the leading journal in the subdiscipline, Political Geography. When the feminist geography journal, Gender, Place and Culture, was launched in the early 1990s, it did not have politics in the title. Likewise, in the 1999 draft chapter for political geography in the Geography in America tome, there is virtually no mention of feminist geography. More optimistically, however, a section on sexuality and space is included. Feminist geographer Lynn Staeheli (1999) has lamented the paucity of connections between feminist geography and political geography, and the persistence of these two solitudes. The political turn I propose aims to traverse these very distinct parts of geography. I do this with a focus on geopolitics at the transnational, or global, scale. $^{3}$

My goal in the remaining minutes is to sketch a hypothetical entry for feminist geopolitics for, say, the next edition of the Dictionary of Human Geography. Such an entry would ideally appear under 'feminist geography' and under 'geopolitics'. I will begin with a few definitions and then outline some contributions to geography that are both feminist and political. Using both Canadian examples and illustrations from further afar, I aim to ground the concept of feminist geopolitics.

Feminist geopolitics, in my view, spans a range of subjects and scales, from the global economy in which Mexican women work in multinational maquiladoras, sewing Jantzen swimwear for $\$ 6$ day (work that was once done in Vancouver); to nationalist projects in which Bosnian Muslim women are raped in camps; to cosmopolitan Canadian cities where refugees from places like Burma negotiate new identities based on their connections to more than one place and struggle to support those left behind in Thai refugee camps. Each of these examples illustrates the ways in which relations of power at different scales (global, national, urban) are linked. They illustrate that global processes, whether economic, political, or socio-cultural, are experienced in localized, everyday, embodied ways. 


\section{Definitions}

For the purposes of my hypothetical dictionary entry, I define the 'feminist' part as analyses and political interventions that address the unequal and often violent relationships among people based on real or perceived social, economic, political, and cultural differences. ${ }^{4}$ There is more than one kind of feminism, and I do not wish to fix the notion of feminist in any singular manner. ${ }^{5}$ Nor do I want to suggest that feminist geopolitics is a new theory of geopolitics or a new order of space. To avoid a singular notion of feminist politics, I will refer to a feminist geopolitical analytic or imaginary. ${ }^{6}$

None of the definitions of geopolitics, as outlined in the new Dictionary of Human Geography (Johnston et al. 2000), begin to describe the notion of geopolitics I want to offer here, one that is accountable to people who occupy particular places, not only states; one that is responsive to groups rendered vulnerable by conflict, not to ethnocentric accounts of West and East; and one that bespeaks fair play and change where warranted for those who man and woman the global economy, not an abstract coreperiphery problem or merely an issue of locational rationalization in a world dominated by multinational corporations. Don't get me wrong: the relations of power promulgated by geographically footloose multinational corporations are an important focus of geography, but what I seek here is an embodied feminist geopolitical perspective that examines the implications of such mobility for the places and people on the ground, a perspective quick to analyze and document relationships that are blatantly exploitative or violent and to change them.

In the current edition of the Dictionary of Human Geography, Graham Smith (2000) outlines four perspectives under the geopolitics entry:

1 Traditional geopolitics, à la Halford Mackinder

2 Power-relations perspective, the realist school of international relations theory

3 Political economy approach

4 Critical geopolitics

Of these, only one perspective provides analytical tools and insight into the feminist geopolitical perspective. While many feminists in political science and a handful in geography have provided sustained and incisive critique of international relations (IR) theory (Peterson 1992; Pettman 1996), these analyses have failed to go beyond the narratives of international relations. That is, feminist critics and IR pro- ponents alike are working within a modern problematic of geopolitics that is insufficient.

It is the scholarship of critical geopolitics that proves most useful to feminist geographers. Critical geopolitics is a sub-field of political geography that emerged in the late 1980s, of which Canadian geographer Simon Dalby (1991) has been a major proponent. Critical geopolitics is a useful departure point and antecedent to a feminist geopolitical imaginary. Drawing inspiration from the work of Michel Foucault and Jacques Derrida, critical geopolitics is less a theory of how space and politics intersect than a taking apart of normalized categories and narratives of geopolitics. Critical geopolitics is about questioning assumptions in a taken-for-granted world and examining the institutional modes of producing such a world vis-à-vis writing about the world, its geography and politics.

Within the rubric of critical geopolitics, Dalby (1994) documents feminist research and demonstrates the ways in which geopolitical categories of security are gendered. He reminds readers of the gender-blind analysis of much IR theory. His comprehensive overview of gender and feminism in IR underscores the relative absence of feminist voices in this area of geography, with notable exceptions (Kofman and Peake 1990; Staeheli 1994; Kofman 1996; Sharp 1996).

While critical geopolitics is useful for a feminist geopolitical analysis, its deconstructive impulses are insufficient to generate change for building alternative futures. With a few exceptions (Dalby 1994; Sparke 1996), the scholarship on critical geopolitics ignores the gendered landscape of dominant geopolitical debates. Critical geopolitics decentres the nation-state and exposes the investments that our dominant geopolitical narratives embody, but it does not put Humpty Dumpty back together again, so to speak. Nor does it question why Humpty is always falling off the wall. We are left with well-interrogated but tacitly masculinist categories, and no clear way forward in practice.

So, what steps could be taken to forge a feminist geopolitical approach? I will mention just three, and then elaborate briefly on each:

1 Shifting scales to employ analyses both finer and coarser than that of the nation-state or global economy;

2 Transposing feminist analyses of the public/private divide to a transnational scale; and

3 Employing mobility as an analytic of geopolitical power and accountability. 


\section{Shifting Scales}

Instead of focusing on the security of states, as international relations theory tends to do, a feminist geopolitics focuses more on the security of persons. Feminists have noted the lack of attention to gender at the intersection of international relations theory and critical geopolitics, one that reiterates an issue long raised by feminists: 'security for whom?' This is a vital question for feminist geopolitics because state security and human security are not necessarily synonymous. The security of the Federal Republic of Yugoslavia in 1999 was not at all synonymous with the security of a segment of its citizenry, namely ethnic Albanian Kosovars. As the Kosovars' experience so vividly illustrates, state-sponsored violence can be waged against targeted groups of citizens, forcing them to flee for their lives. A feminist geopolitical approach unsettles the conventions of state security by introducing both finer and coarser scales of analy. sis as well as action. Security of person for Kosovars precedes the security of violent states from a feminist geopolitical approach. From the same perspective, the insecurity caused by NATO attacks on civilians and civilian installations renders it an unacceptable strategy for providing stability. As an approach, and not a theory or strategy, feminist geopolitics insists upon the contingency of place, people, and context in making change.

To ground the idea of shifting scales, I now turn to an analysis of 'human security', a central part of Canadian foreign policy at the present time. 'Human security' is a relatively recent concept in foreign policy and multilateral affairs, one which has been adopted by the Canadian Government as part of it peace-building initiative. It stems from the 1994 United Nations Development Program's (UNDP) Human Development Report in which a broad notion of security is advocated, encompassing economic security, food security, health security, environmental security, and has personal, community, and political dimensions (DFAIT 2000).

Human security, in theory, disaggregates the broader notion of security to a finer scale at which smaller political constituencies and vulnerable groups become visible. Human security, as Canadian foreign policy, stands alongside but is distinguished from state security. It disaggregates and shifts the focus of state security to a finer scale, namely that of individuals and groups. To the extent that human security accomplishes this task of redefining scale, it can be considered part of feminist geopolitical analytic that aims to reconstitute the territorial foundation upon which security is based, and exposes those who are effaced or harmed by policies in the name of state or global security. ${ }^{7}$ Its attention to the security of individuals and groups in the broadest sense highlights the importance of scale to political struggle (Staeheli 1994).

Scale is "a contingent outcome of the tensions that exist between structural forces and the practices of human agents" (Marston 2000, 220). The theory of human security thus proves harder to implement. The persecution of ethnic Albanian Kosovars by the Serbian government of Slobodan Milosevic provided an opportunity for the implementation of human security principles. To the extent that the NATO intervention was predicated on the belief that the rights of an ethnic and religious minority under siege prevailed over the right of a sovereign state to govern and take independent action within its borders, the decision upheld the principal of human security and safety of a persecuted minority. The means of intervention, NATO air strikes on Serbia beginning in March 1999, however, is much more problematic from a human security perspective, as violence against Kosovars and Serbian civilians escalated with the NATO attacks. Serbian violence against Kosovar Albanians was used to warrant the suspension of Yugoslav state sovereignty for the purpose of NATO's bombing: indirectly, NATO state-sponsored violence was met with Serbian state-sponsored violence. Human security is susceptible to politicization. In this case, it was used as a justification for intervention, a move that, in turn, caused further insecurity, putting in jeopardy the very lives of Kosovars. The tactical and geographical logic behind the NATO attacks has been widely criticized.

The either/or binary offered up by Western leaders during the Kosovo crisis represented a very limited geopolitical imagination: either attack the Serbs, or ethnic Albanians in Kosovo will be annihilated. ${ }^{8} \mathrm{~A}$ number of feminist groups worldwide, in particular Women in Black, noted that "neither/nor" was an option that received little attention (Cockburn 2000). A military aerial attack was presented as the obvious if not only option (Figure 1).

That the UN Security Council did not authorize the NATO attacks is significant. Protecting state sovereignty and refusing the precedent of international humanitarian intervention in a 'rogue' nation were crucial issues for two of the five permanent countries 


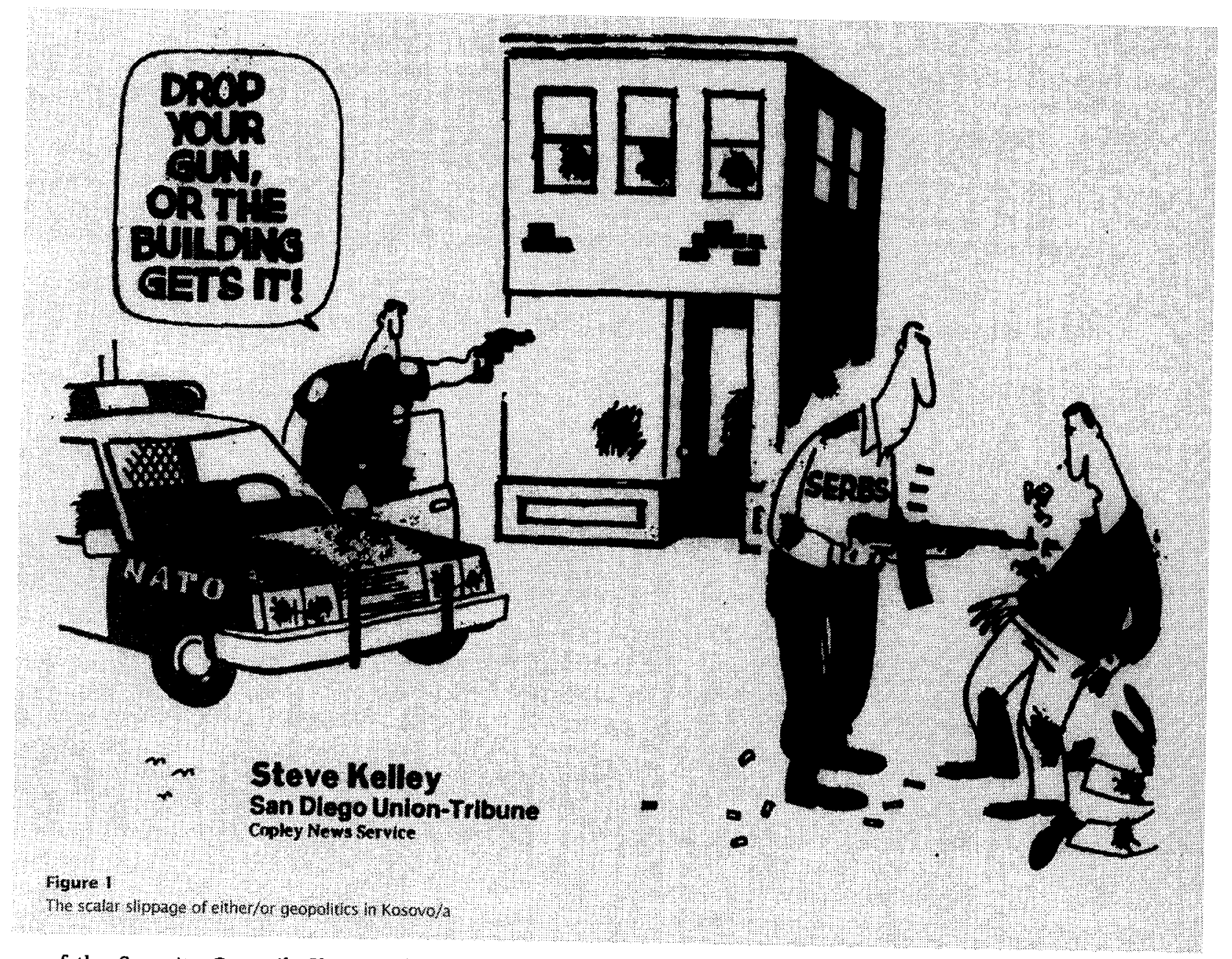

of the Security Council: China and Russia. Each has its own so-called 'domestic' conflict with the Tibetan independence movement and Chechen rebels respectively. Let me interrogate this idea of domestic versus international politics, and suggest that the divide is an arbitrary one that does not necessarily serve to ensure safety among civilian populations.

\section{Challenging the Public/Private Divide}

Feminists within and beyond geography have long challenged the demarcation of a private/public divide, particularly the social and spatial separation of unpaid work at home versus paid work in the public sphere, and the idea that citizenship is gendered because of its primary location in the public space. The politics of public and private, however, have been less scrutinized at a global scale. Some entry

points into such an analysis are worth mentioning; let me provide three examples.

First, a significant shift in world affairs is occurring whereby the security of persons has been put on more equal footing with sovereignty and the security of states. While international law and the discourse of human rights have long existed, their mobilization by states, regional bodies, and suprastate organizations, such as the UN Security Council, appears to be increasing. The principles associated with human security, for example, fall into this category: the idea that state security is but one of several axes of security that traverse a number of scales.

The contradiction between state security and the security of persons can be traced to the potentially contradictory terms enshrined in the UN Charter and the UN Declaration of Human Rights. While the UN 
Charter has mechanisms to ensure the protection and enforcement of peace and international security, there are no similar duties or obligations in the Charter for the protection of human rights. Instead, these are outlined in the legally non-binding UN Declaration of Human Rights. However, interpretation of the Charter by the UN Security Council over the past decade has extended the meaning of what constitutes a threat to international peace and security, and has thus extended the geographical scope of what counts as public. Previously, the domestic affairs of states were seen to be private matters, beyond the purview of the Charter's provisions. Where threats to international peace and security were once predicated on attacks by states against other states, they now include threats made by a state against segments of its own population. Sovereignty is qualified, and the abrogation of people's rights within a given state are no longer a domestic matter. The geographical scope of the Charter has shifted.

A second example of the way in which private/public divides are being challenged is through the international legal system, specifically by the two War Crimes Tribunals for the Former Yugoslavia and Rwanda. ${ }^{9}$ In June 1996, for the first time in history, the tribunal for Yugoslavia prosecuted rape as a weapon of war and a crime against humanity" (Kirshenbaum et al. 1997, 64). It issued indictments for the arrest of eight men, charged with sexual assault for the purposes of torture and enslavement. Ample evidence that men used rape to terrorize, humiliate, and contaminate the women of opposing ethnic groups in Bosnia-Herzegovina led to the indictments. 10 "To rape women with impunity and to mark their bodies with the symbols of the other side is to assert domination and to symbolically assault ethnic identity in its most protected space" (Coomaraswamy 1999, 10). Men were also raped and sexually mutilated; in some cases they were forced to rape or sexually mutilate other men (Pettman 1996). People's bodies are construed as territory and become the sites of public violence on which symbolic constructions of the nation and its boundaries take place (ibid.; Giles and Hyndman forthcoming).

The ruling that rape is a weapon of war, however, is significant because it publicizes sexual violence as a weapon of war. Sexual violence and rape are as old as war itself, but until now these issues have been rendered invisible or incidental because they were dismissed as private acts, the "aberrational practices of errant soldiers" (Coomaraswamy 1999, 3). The tacit theatre of war was the battlefield, the public space around which the rules of war - the Geneva Conventions - have been written. But the public/private divide between the battlefield and civilian bodies has dissolved. People's bodies, homes, communities, and livelihoods have become the battlefields of contemporary conflict. By identifying rape as a strategic weapon of war, its violence is recorded as a public act and punishment for such crimes is legitimized. Rape is not simply an addition to international humanitarian and human rights law. It represents a new category of crime that reorganizes the scale and scope of punishment, and recasts what counts (that which is public) and what does not (that which is considered private). The safety of the body as the finest scale of geopolitical space is politicized.

A third example of the perils of public/private divides is evidence of spousal or wife abuse recently reported among families in the Canadian Armed Forces (Mitrovica and Sallot 2000). Despite an informal zero-tolerance policy towards spousal abuse, the report - based on 126 interviews with survivors of violence at home-documents that many abused women were driven into silence because commanders believed such issues would be best dealt with in the civilian justice system (Muriel McQueen Fergusson Centre for Family Violence Research et al. 2000). The research reveals that a code of solidarity exist among armed forces personnel, so that members did not go forth with public prosecution against their fellow soldiers. This privatization of violence to the domain of the family was further exacerbated, in my estimation, by commanders' preference that such charges be dealt with by the civilian justice system, relegating spousal abuse to yet another domain beyond the army's jurisdiction.

Vulnerability to abuse is accentuated by geographical isolation from friends and relatives, and economic dependence on a sole male breadwinner. Rendering visible and public the experience of those abused represents a first step towards addressing the violence and power relations among military families. Further research on the culture and training of armed forces personnel in Canada is needed to connect the domains of militarized masculinity at work with the performance of masculinity at home. 


\section{Mobility and Accountability}

Employing mobility as an analytic of geopolitical power opens up possibilities for feminist politics. People's mobility varies tremendously across race, gender, class, nationality, immigrant status, ability, and many other factors. Gender and socio-economic status shape mobility in important ways. My past research has analyzed the differential access of Somali and Sudanese refugees in Kenya to Canadian and Australian visa posts where they can apply for resettlement overseas. Refugee camps based in rural Northeast Kenya are far from the application office for the Canadian and Australian High Commissions in Nairobi, making access for those who must care for children in the camps and/or those without the means to travel to Nairobi much more restricted (Hyndman 2000).

Furthermore, the forced migration of internally displaced persons (IDPs) and refugees is an increasingly pressing issue. There are some 14 million refugees and 21 million IDPs world-wide (US Committee for Refugees 2000). The geography of their displacement is uneven, but in all cases is closely related to conditions of state terror, conflict, and/or violence. As Ken Hewitt (2001) has pointed out, "such issues are virtually absent from our academic literature [in geography]." Hewitt's analysis of Pinochet and Kropotkin in this volume begins to fill the gap in understanding the processes that perpetrate violence, shape mobility, and generate displacement.

Mobility not only provides a basis to analyze power relations across space and among groups with lesser or greater social or economic status, but controlling mobility can also be the basis of political intervention against those who have abused power. One can specify a 'geo-politics of mobility' that calls for an integrated analysis of political networks and nodes of financial power within the global economy, power relations that shape the mobility of particular groups or individuals (Hyndman 1997). The mobility of people indicted for war crimes and other crimes against humanity is increasingly restricted. To the extent that perpetrators of such violence are geographically confined and forced to answer for their actions within the context of their civil society, and local institutions of justice where possible, such confinement can serve feminist ends. Such immobility can allow for a more accountable, embodied, and responsive notion of geopolitics.

The recent spat among European countries about the fate of General Augusto Pinochet provides a good example of the critical role mobility plays in meting out justice across scales. ${ }^{11}$ On October 16, 1998, General Pinochet was arrested in London while seeking medical treatment. A warrant issued by a Spanish judge outlined some 35 charges of torture and conspiracy to torture, as grounds for arrest and extradition. Some Spanish citizens were among the tortured (Crossette 1999). In March 1999, the Law Lords in Britain ruled that General Pinochet's arrest was lawful, opening the way for an extradition hearing. In a partial victory for Pinochet, they said he is not answerable for charges of human rights abuse committed before 1988 when Britain incorporated the UN convention on torture into law. More than 3000 people were executed or disappeared during the Pinochet dictatorship. By October 1999, a British court ruled that General Pinochet could be extradited to Spain to stand trial there on charges. In January 2000, a British High Court judge issued a verdict supporting the British government's decision to release General Pinochet. He added that "in legal, if somewhat peremptory terms, it is none of their [the complainants'] business" (Hoge 2000). Belgium immediately appealed the judgement, countering the judge's attempt to privatize the issue as a British-only matter. Despite the efforts of several countries, Pinochet was allowed to fly home to Chile in March 2000.12 On January 31, 2001, he was served with an order for house arrest which is being appealed on the basis of ill-health (The New York Times 2001).

Regardless of Pinochet's return to Chile and his fate there, a valuable legal precedent has been set for the human rights movement, one which is potentially valuable to a feminist geopolitics concerned with generating parameters of accountability and rendering places and peoples safer: former heads of state do not enjoy immunity from prosecution for systematic atrocities. "It is a shame that Pinochet may never have to stand trial, but the very fact that he was arrested and that his crimes were presented before a court has already changed the calculus of dictators all over the world" (Brody cited in Knox 2000).13 Whether this will give would-be dictators pause for reflection is uncertain, but there remains the political possibility that perpetrators of heinous crimes will be deterred from committing such acts at best and will not be able to move freely during their lives in exile at a minimum. Based in large part on the Pinochet case, the mobility of former heads of state who commit such atrocities is increasingly restricted. ${ }^{14}$ 
This precedent has broad mobility implications for all kinds of people who might have committed crimes against humanity or war crimes for which they have not been held accountable. In August of 1999, Vienna city councilman, Peter Pilz, discovered that Izzat Ibrahim al-Duri - a man with a deplorable record of human rights violations as Saddam Hussein's deputy - was in Vienna for medical treatment. Mr. Pilz promptly filed a criminal complaint with Austrian authorities and within 48 hours, Mr. Ibrahim fled (Crossette 1999). Usually, it is refugees who flee, not dictators. A week later, also in Vienna, General Momir Talic was detained by Austrian authorities as an indicted war crimes suspect. This was the first time a sealed indictment had led to an arrest outside Bosnia. The chief of staff of the Bosnian Serb army had been in town for a conference at the National Defense Academy, and was unaware that he had been charged in a secret indictment with crimes against humanity during the 1992-95 Bosnian War.

While the forced migration of civilians because of war, persecution, and violence continues, it is increasingly those responsible for such scatterings who are the target of mobility checks and human rights enforcement when these suspects go beyond the boundaries of their safe countries. Under former President Suharto's rule, Indonesia invaded East Timor in 1976 and imposed repressive rule on its people until he left office in 1998. A leading Jakarta paper reports that former President Suharto, who was forced from office after three decades of autocratic rule, was under investigation by the new Indonesian government. Mr. Suharto, 78, lives at home in Indonesia but had been expected to seek medical treatment in Germany, where he has travelled in the past for a stroke and internal bleeding in July 1999. People close to the family told The Jakarta Post that travel outside of Indonesia was unlikely due to potential warrants for his arrest (Crossette 1999). Mr. Suharto has since been too sick to stand trial, despite requests to that effect.

And finally, the Ethiopian government has called on South Africa to extradite its former president, Mengistu Haile Mariam, to face charges of human rights violations (The New York Times 1999a). Mengistu fled to Zimbabwe in 1991 when his government was overthrown after sixteen years in power. He sought medical treatment for a heart ailment in South Africa late in 1999. The South African foreign ministry first announced that Mr. Mengistu,
62, would not be extradited to Ethiopia where he faces charges of mass killings of political opponents. He was considered, ironically, a refugee (The New York Times 1999b). A week later, under pressure from human rights groups, the South African government agreed to review Ethiopia's request to extradite the exiled dictator (The New York Times 1999c). The matter is pending. Each of these scenarios introduces the political problems of geography faced by political leaders guilty of abusing power.

Many former dictators who have blood on their hands still enjoy exile in countries that agree to host them. Idi Amin, for example, lives safely in Saudi Arabia without threat of extradition. Where war crimes and crimes against humanity have gone unpunished because their perpetrators hide behind sympathetic borders, these perpetrators are increasingly being questioned the moment they cross such boundaries. One unintended consequence of this new political will to see justice served is the increasingly restricted mobility of perpetrators; those who have abused their power potentially face a geography of containment in their home country, or within a few allied states. The charges outlined in the scenarios above span the political spectrum, from right to left, and while selective, they do not simply signal a strategic reinactment of foreign policy to national ends.

The Pinochet ruling has raised concern among former American officials that they too could some day be extradited. Oliver North acknowledged that "It [the Pinochet ruling] limits my travel to certain countries" (Blair 2000). But the same kinds of crimes deal different outcomes when the perpetrator comes from the world's sole remaining superpower: "The political reality is that it [arrest] is very remote.... Why? Because we are the superpower. It would be very dangerous for another country to do that economically, politically and otherwise," says Jonathan Charney, a law professor at Vanderbilt University. Patricia Derian, the US first assistant secretary of state for human rights, counters that she can foresee the day when American officials would be prosecuted for acts similar to those attributed to James Baker, Oliver North, and Henry Kissinger (ibid.). As before, universal standards or rights of citizenship never apply equally across space. 15

The limits of international law are being tested in new ways that challenge current thinking in feminist and political geography. The link between mobility and rights remains an under-explored area of geo- 
graphical research (Blomley 1994), as is the relationship between mobility and displacement. What work has been done with respect to rights tends to focus on the important social differences in accessing mobility rights within a national context where such rights are constitutionally enshrined. But the link between mobility and rights can be forged from another angle and at different scales. The preceding examples suggest that once powerful leaders who now constitute an elite class of itinerant exiled dictators are not as free to move as they would have been had they not [allegedly] abrogated the rights of others during their tenure of political leadership. In this view, mobility for perpetrators of heinous crimes is restricted as states refuse to guarantee their protection when they enter their countries. Human security, while geographically uneven, appears to take precedence over sovereign leaders and matters of state security. After the Pinochet drama in Europe, it is clear that much of Europe would be off limits to former presidents such as the now-deceased Mobutu Sese Seko of Zaire, who spent more time in Europe than his own country.

How consistent are such attempts to redress injustice across space and political context? Not all countries are as vigilant as others. A 1994 Canadian Supreme Court ruling upheld the acquittal of Hungarian police captain, Imre Finta, on grounds that he was merely following orders when he deported Jews to death camps, despite codification in international law that 'following orders' does not exempt a person from responsibility for his/her actions (Knox 1999). On a more positive note, in West Africa, courts in Senegal recently indicted Hissène Habre, the exiled former dictator of Chad on charges of torture. The indictment is the first in which a former African head of state has been charged with human rights violations by the court of another country. ${ }^{16}$ Senegal is a signatory to the UN Convention Against Torture that obliges, but does not enforce, states to prosecute or extradite torturers who enter their territories. ${ }^{17}$

I do not simply endorse punitive measures of justice at international tribunals. Such 'universal' norms of justice are unavoidably ethnocentric and political. ${ }^{18}$ Where possible, national and local institutions of justice or methods of reconciliation are often preferable. Responsibility for collective guilt, and subsequent social change, for example, is more likely to be taken seriously by a nation that tries itself in the context of its own civil institutions, than by a foreign court that prosecutes the leaders of that nation.
The politics of containment that these arrests shape serves feminist geopolitical political goals to the extent that local, national, and sometimes international approaches to justice can be meted out. A feminist geopolitical project relies upon a commitment to the safety and well-being of persons rather than states, but also on a healthy civil society with good access to information, strong independent media, and active non-governmental organizations that do not tolerate systematic acts of violence against its citizenry.

\section{A Concluding Remark}

In closing, a feminist geopolitics does not promote a new theory of geopolitics. It does not usher in a new order of space, nor advocate an alternative universal standard of practice. Rather, it embodies an approach that advocates a finer scale of 'security' accountable to people, as individuals and groups, and analyzes the spaces of violence that traverse public/private distinctions. A feminist geopolitical approach examines mobility in terms of access and accountability. It does not aim to endorse a single set of judicial practices or institutions, nor even a punitive approach to justice, but does underscore a quest to improve the security of people at the finest scale by strengthening the institutions of civil society in situ. By asking, 'security for whom?' a feminist geopolitical analytic identifies the geographically and historically contingent practices which promote the security of persons, and reconstructs geopolitics as we know them.

\section{Notes}

1 The following address was presented at the 2000 Canadian Assoctation of Geographers (CAG) conference in memory of Dr. Suzanne Mackenzie; it has been lightly edited to incorporate answers to questions posed at the end of the presentation, and in response to thoughtful comments by two anonymous reviewers.

2 My reliance on Canadian feminist geographers in this talk is not accidental. My work is heavily indebted to the scholarship and actions of feminist geographers in this country.

3 Transnational theorizing departs from the assumption that nations, states, or communities can be treated as spatially independent entities (see Hyndman and Walton-Roberts, 2000).

4 Gender remains a central concern of feminist politics and thought, however, its primacy over other positionings is not fixed across time and place. Daiva Stasiulis $(1999,194)$ elaborates on the importance of relationality, positionality, and 'relational positionality' to feminist politics: "They refer to the multiple relations of power that intersect in complex ways to position individuals and collectivities in shifting and often contradictory locations within geopolitical spaces, historical narratives, and movement politics." Stasiulus maintains that 
"Central to my interpretation of relational positionality is also a rejection of postructuralist deconstructions that deny the material bases for power relations, however complicated their discursive representations" (ibid., 196). I would agree with Stasiulus here, though argue that poststructuralist analyses do not categorically deny the material bases of power relations, and that they can in fact reveal the processes by which particular constellations of power are are effaced or naturalized.

5 As Vera Chouinard (2001) has argued, struggles against the marginalization of citizens disadvantaged by embodied differences such as race, gender, and mental or physical impairment, often focus on legal rights.

6 A feminist imaginary is a universe of politically possible interventions, actions, and alliances. It encompasses the possibility of both alternative modernities and the very concrete expressions of or changes within a specific modernity. In my view, it differs from theory in that it encompasses contingent normative engagements and thus offers a more embodied and accountable politics. The distinction between a universe of potential modes of engagement (my notion of feminist geopolitics) and universalist notions of what engagement should look like (in which modernity is singular and status quo) is another way to get at this difference. Dilip Parameshwar Gaonkar (1999) argues for site-based readings of modernity that resist any inexorable logic assigned to modernity. Each national and cultural site represents a contingent formation based on local politics and culture. Charles Taylor $(1999,162)$ adds that "modernity, taking place in different civilizations, will produce different results that reflect their divergent starting points.... instead of speaking of modernity in the singular, we should better speak of 'alternative modernities'." I thank Priti Ramamurthy for her insights on alternative modernities in response to some of the ideas voiced here.

In the context of critical geopolitics, Matt Sparke (2000) argues that there are 'real-worlders' and more critical geographers who are committed to revealing the relations of power which underwrite the knowledge production of 'real-worlders'. The real-worlders are unable to question the premises on which their knowledge is enabled and limited. A feminist geopolitical imaginary, then, begins with the idea that certain geopolitical stories and practices dominate and that their investments can be exposed through critical analysis. But this is not sufficient. There is also a real-world component, one that employs other notions of modernity and of historically and geographically contingent engagement in feminist process, response, and coordinated action. This might involve, as I indicate, restricting the mobility of those who violate others in violent and systematic ways.

7 Upholding the human rights of individuals, including economic, social, and cultural rights, human security in theory improves upon the Western bias on civil and political rights since WWII, and provides a more comprehensive basis for foreign policy and practice.

8 A sustained critique of such dualist thinking can be found in Kobayashi and Peake (1994).

9 One criticism of this talk revolved around the very 'humanist' notions of justice and politics described. While $I$ understand the limitations of what I have called 'UN humanism', I am not simply endorsing the ways in which justice is meted out by the international war crimes tribunals. As Dianne Martin and Mark Drumbl have written, "the increased criminalization of gendered crimes and hate crimes represents a reinforcement of retributive criminal justice model", one that may well be counter-intuitive to feminist politics (Drumbl 2000, 22) One must consider the context of such crimes and the goals of any response: is the aim reconciliation among segments of a shattered society? Is it punishment, so that by prosecuting perpetrators a local sense of justice is achieved, and civil society can resume? Is the aim political, t.e. to bring major war criminals to 'justice' for the satisfaction of certain allied governments on a more international scale? 1 thank Adrienne Burk for her insights on these geographies of justice and collective memory. Thanks also to Dan Hiebert for making me think much more about these issues.

10 An estimated 20,000 women endured sexual assaults in the form of torture and rape during the war in Bosnia-Herzegovina (Salzman 1998). In Rwanda, the estimated number of rapes in the context of genocide is 250,000 (Drumbl, 2000).

11 The geography of state terror imposed by Pinochet was adroitly analyzed by Ken Hewitt in his John Wiley Lecture at the Annual Meeting of the Canadian Association of Geographers in June 2000 (see Hewitt, 2001).

12 Asserting Chile's sovereignty in the matter, former president, Eduardo Frei [replaced in March 2000 by Ricardo Lagos of the Socialist Party]. argued that the attempts to extradite and prosecute General Pinochet are unnecessary because he could just as easily stand trial in Chile. While a senior Chilean judge has sent Pinochet questions about his involvement in the various crimes for future trials, human rights activists are skeptical about Frei's claim because no judge in Chile has challenged the parliamentary immunity against prosecution that General Pinochet has as senator-for-life (Krauss 1999)

Since the arrest of Pinochet abroad, twenty-five Chilean officers at home have been arrested on various charges of murder, kidnapping, and torture, including sexual slavery, electric shock treatments, and beatings. "And Government officials privately predict that a long list of generals and other officers once though untouchable will be arrested during the next year" (Krauss 1999). Ceneral Umberto Gordon, a member of Ceneral Pinochet's four-man junta and chief of his secret police, was arrested in September 1999, making him the highest ranking military officer ever to be detained and prosecuted in Chile. While some speculate that the arrest of Pinochet in Britain sparked a more activist judicial system at home, an important Supreme Court decision in July 1999 provides hard evidence of more liberal civilian judiciary. The Court upheld a decision that an amnesty declared by the former Pinochet government to protect military officers from the crimes committed between the 1973 coup against Mr. Allende and March 1978 was no longer applicable to cases in which people had disappeared. Until bodies could be accounted for, the crimes were not murder but kidnapping, meaning that the original crime was a continuing event beyond the 1978 deadline. In the Chilean context then, there is no place to hide: to flee is to be arrested, as in General Pinochet's case, but to stay home also may involve the redress of past injustices for many perpetrators of crimes against humanity. In August 2000, The New York Times reported that, "The Chilean Supreme Court voted in secret today to strip Gen. Augusto Pinochet of his senatorial immunity, according to local radio and web site accounts. The decision would remove the last legal obstacle to a full-scale criminal investigation of the former dictator and would permit his trial on charges of kidnapping, murder and torture" (Krauss 2000).

13 This calculus of mobility can be read as an expression of modern geopolitics: "[a]n essential aspect of the modern attitude to pain rests on a calculus that defines appropriate actions" (Asad 1997, 303). Just as torture is defined by an excess of violent and/or degrading treatment, so too is mobility a matter of measure.

$14 \mathrm{My}$ focus on mobility in this brief talk belies much larger questions about what mechanisms would best serve the goals of social justice, national memory, and collective responsibility where government institutions, and not simply individuals, perpetrated crimes against humanity. Whether international war crimes tribunals, local trials, or truth commissions are most appropriate begs further analysis regarding the purpose of seeking 'justice', the practicalities of what is possible, and the circumstances surrounding the alleged crimes. 
15 US intransigence in ratifying UN conventions is also well-known. International treaties undergo extensive examination and scrutiny before they are ratified in the United States; it can take several years for a treaty to be ratified after it is signed. For example, the Convention on the Prevention and Punishment of the Crime of Genocide took more than 30 years to be ratified by the United States, and the Convention on the Elimination of All Forms of Discrimination Against Women, which was signed by the United States 17 years ago, still has not been ratified. Signed by the U.S. just over two years ago, the Convention on the Rights of the Child has also not been ratified.

Nor has the US become a signatory to the International Criminal Court, a proposed permanent international tribunal initiated in 1998. Some governments believe that US opposition may give the court more credibility when it is established, while others argue that it reproduces a retributive and punitive criminal justice paradigm that may be counter-intuitive to feminist politics (Drumbl, 2000). Nonetheless, the countries that are signatories represent areas that would be 'out of bounds' for people indicted for war crimes and crimes against humanity.

16 Senegal was, at the time, heading into an election.

17 International human rights instruments are crucial to these indictments and prosecutions. They include the Convention on the Crime of Cenocide (1948); the Convention on the Elimination of Discrimination Against Women (1979), the Conventions Against Torture (1984), the Convention on the Rights of the Child (1989), and the Statute of the International Criminal Court (1998) (see Bruderlein 1999).

18 The recent election of Vojilslav Kostunica as the new president of the Federal Republic of Yugoslavia marks the end of the Milosevic era. Kostunica has, however, made it clear that he views the Hague as an anti-Serb, pro-American court and has vowed not to send $\mathrm{Mr}$. Milosevic there (Erlanger 2000). The US Congress, in turn, approved an aid package to Serbia in October 2000 , contingent upon Kostunica's cooperation in apprehending those indicted on charges of war crimes, in particular, Mr. Milosevic (Holmes 2000). On June, 2001 , the Yugoslav cabinet adopted a decree committing itself to sending the former president, Slobodan Milosevic, to the United Nations tribunal in The Hague to face trial on charges of war crimes.

\section{References}

ASAD, T. 1997 'On torture, or cruel, inhuman, and degrading treatment', in Social Suffering, eds. A. Kleinman, V. Das and M. Lock (Berkeley: University of California Press) 285-308

BLAIR, J. 2000 The World - Pinochet's revenge: Oliver North, you'd better watch out' The New York Times March 26, Week in Review Desk

BLOMLEY, N. K. 1994 'Mobility, empowerment and the rights revolution' Political Geography 13, 407-422

BRUDERLEN, C. 1999 Towards a New Strategic Approach to Humanitarian Protection and the Use of Protected Areas. Final report of the consultation for Office for the Coordination of Humanitarian Affairs (OCHA) and Harvard Center for Population and Development Studies, Cambridge MA, May 6 (mimeo)

CHOUINARD, v. 2001 'Legal peripheries: struggles over disabled Canadians' places in law, society and space' The Canadian Geographer 45, 187 . 192

COCKBURN, c. 2000 'Women in black: being able to say neither/nor' in Canadian Woman Studies, Special Issue 'Women in Conflict Zones' 19 (4), 5-10

COOMARASWAMY, R. 1999 'A question of honour: women, ethnicity and armed conflict' Third Minority Rights Lecture, Geneva, May 25 (mimeo)
CROSSETTE, B. 1999 'Dictators Face the Pinochet Syndrome', The New York Times, August 22, Week in Review Desk section

DALBY, S. 1991 'Critical geopolitics: discourse, difference, and dissent', Environment and Planning D: Society and Space 9, 261-283

- 1994 'Gender and critical geopolitics: reading security discourse in the new world order,' Environment and Planning D: Society and Space $12,595-612$

DEPARTMENT OF FOREIGN afFAIRS AND INTERNATIONAL TRADE (DFATT) 2000 'Freedom from fear: Canada's foreign policy for human security' http://www.dfait-maeci.gc.ca/forejgnp/HumanSecurity/ HumanSecuritysBooklet-e.asp, accessed October 10, 2000

DRUMBL, M. 2000 'Punishment goes global: international criminal law, conflict zones, and gender (in)equality' Canadian Woman Studies, Special Issue 'Women in Conflict Zones' 19, 22-27

DYCK, L. 1997 'Dialogue with difference: a tale of two studies' in Thresholds of Feminist Geography: Difference, Methodology, Representation, ed. J.P. Jones III, H. J. Nast, and S. M. Roberts (Berkeley: University of California Press), 183-202

ERLANGER, S. 2000 The world; the Serbs ask a chance to judge their own guilt, The New York Times, October 15, Week in Review Desk section

FOORD, J., BOWLBY, 5., LEWIS, J. and MCDOWEL, L 1999 'Remembering Suzanne...' in Gender, Place, and Culture 6, 408-411

GILES, w. and J. HYNDMAN forthcoming 'Shifting sites of gendered and militarized violence' in Sites of Violence: Gender and Violence in Conflict Zones, eds. W. Giles and J. Hyndman (Los Angeles/Berkeley: University of California Press)

GAONKAR, D. P. 1999 'On alternative modernities', Public Culture 11(1), 1-18

HANSON, S. and PRATT, G. 1995 Gender, Work, and Space, (New York: Routledge)

HEWTT, K. 3. 2001 'Between Pinochet and Kropotkin: state terror, human rights and the geographers,' based on the John Wiley lecture at the annual meeting of the Canadian Association of Geographers, Brock University, June 2, 2000, in The Canadian Geographer 45, forthcoming

HOGE, w. 2000 'Britain's high court supports move to release Pinochet,' The New York Times, February 1, Foreign Desk section

HOLMES, S. A. 2000 '\$100 million voted for Serbia, but with war-crimes strings,' The New York Times, October 26, Foreign Desk section

HMNDMAN, J. 1997 'Border Crossings' Antipode 29, 149-176

- 2000 Managing Displacement: Refugees and the Politics of Humanitarianism (Minneapolis: Minnesota University Press)

HYNDMAN, J. and WALTON-ROBERTS, M. 2000 Interrogating borders: a transnational approach to refugee research in Vancouver' The Canadian Geographer 44, 244-258

JOHNSTON, R. J., GRECORY, D., PRATT, G. and WATTS, M. 2000 Dictionary of Human Geography (Oxford: Blackwell Publishers)

KIRSHENBAUM, G. 1997 'Jadranka Cigelj and Nusreta Sivac: efforts to bring the rapists of Bosnian women to justice' Ms. 7 (4), 64-68.

KLODAWSKY, F., ANDREW, C. and uNDY, C. 1994 'Challenging business as usual in housing and community planning: The issue of violence against women', Canadian Journal of Urban Research 3, 40-58

kNOX, P. 1999 'Historic ruling okays Pinochet extradition,' The Globe and Mail, October 9, Al, Al8

KOBAYSH, A. 1993 'Multiculturalism: representing a Canadian Institution' in Place/Culture/Representation eds. J. Duncan and D. Ley (London: Routledge) 205-231

KOBAYSH, A. and PEAKE, L 1994 "Unnatural discourse: "race" and gender in geography' Gender, Place, and Culture 1, 225-243

KOFMAN, E. 1996 'Feminism, gender relations and geopolitics: problematic closures and opening strategies' in Globalization: Theory and Practice eds. E. Kofman and G. Youngs (London: Pinter) 209-224

KOFMAN, E. and PEAKE, L 1990 'Into the 1990s: a gendered agenda for political geography' Political Geography Quarterly 9, 313-336

KRAUSS, C. 1999 'Chilean military faces reckoning for its dark past' The 
New York Times, October 3, Foreign Desk section

- 2000 'Pinochet reportedly stripped of immunity in secret court vote' The New York Times, August 2, Foreign Desk section

MACKENZIE, S. 1989 'Restructuring the relations of work and life: women as environmental actors, feminism as geographical analysis' in Remaking Human Geography eds. A. Kobayashi and S. Mackenzie (Boston: Unwin Hyman) 40-61

-. 1999 'Restructuring the relations of work and life: women as environmental actors, feminism as geographical analysis' reprinted in Gender, Place, and Culture 6, 417-430

Marston, S. A. 2000 'The social construction of scale' Progress in Human Geography 24, 219-242

MCDOWELL, l. and SHARP, J. P. 1997 Space, Gender, Knowledge (London: John Wiley and Sons)

MITRONCA, A. and J. SALLOT 2000 'Military covers up wife abuse, study finds' The Globe and Mail, May 8, $\mathrm{Al}, \mathrm{A} 6$

MOss, P. 1993 'Focus: feminism as method' The Canadian Geographer 37. $48-49$

MURIEL MCQUEEN FERGUSSON CENTRE FOR FAMILY VIOLENCE RESEARCH AT THE UNJVERSTTY OF NEW BRUNSWICK AND THE RESOLVE VIOLENCE AND ABUSE RESEARCH CENTRE AT THE UNIVERSITY OF MANITOBA 2000 'Report on the Canadian Forces' Response to Woman Abuse in Military Families', May; http://www.unb.ca/ web/arts/CFVR/military.html accessed November 2000

THE NEW YORK TMMES 1999a 'Ethiopia: ex-dictator sought,' November 27, World Briefing: Foreign Desk section.

—. 1999b 'South Africa, Ethiopia: no extradition,' November 30, World Briefing: Foreign Desk section.

—. 1999c 'South Africa: Ethiopian faces extradition;' December 7, World Briefing: Foreign Desk section.

- 2001 'Chile: Pinochet appeal', February 2, World Briefing: Foreign Desk section.

OCRAN, A. A. 1997 'Across the home/work divide: homework in garment manufacture and the failure of employment regulation'in Challenging the Public/Private Divide: Feminism, Law, and Public Policy, ed. S. Boyd (Toronto: University of Toronto Press, 1997) 144-167

PETERSON, v. s. 1992 'Security and sovereign states: what is at stake in taking feminism seriously' in Gendered States: Feminist (Re)visions of International Relations Theory, ed. V.S. Peterson (Boulder, Co.: Lynne Rienner) 31-64
PETTMAN, J. J. 1996 'Boundary politics: women, nationalism and danger' in New Frontiers in Women's Studies: Knowledge, Identity and Nationalism eds. M. Maynard and J. Purvis (London: Taylor and Francis) $187-202$

PRATT, G. 2000 'Feminist geographies' in The Dictionary of Human Geography, eds. R.J. Johnston, D. Gregory, G. Pratt and M. Watts (Oxford: Blackwell Publishers) 259-262

PRESTON, v. 2000 'Immigrant women's access to employment in Toronto' paper presented to the Canadian Association of Geographer's Annual Meeting, St. Catharines, Ontario, May 31-June 3 (mimeo)

ROSE, D. 1999 'Suzanne Mackenzie's feminist geography - a personal viewpoint' Gender, Place, and Culture 6, 404-408

RuDoick, s. 1996 'Constructing difference in public spaces: race, class and gender asinterlocking systems' Urban Geography 17, 132-151

SALZMAN, T. 1998 'Rape camps as a means of ethnic cleansing: religious, cultural, and ethical responses to rape victims in the former Yugoslavia' Human Rights Quarterly 20, 348-378

SHARP, J. P. 1996 'Gendering nationhood: a feminist engagement with national identity' in Bodyspace: Destabilising Geographies of Gender and Sexuality, ed. N. Duncan (New York: Routledge) 97-108

SMTHH, G. 2000 'Geopolitics' entry in The Dictionary of Human Geography, eds. R.J. Johnston, D. Gregory, G. Pratt and M. Watts (Oxford: Blackwell Publishers)

SPARKE, M. 1996 'Negotlating national action: free trade, constitutional debate and the gendered geopolitics of Canada' Political Geography $15,615-640$.

- 2000 'Graphing the geo in geo-political: Critical Geopolitics and the re-visioning of responsibility' Political Geography 19, 373-380

STAEHEJ, L. A. 1994 'Empowering political struggle: spaces and scales of resistance' Political Geography 13, 387.391

- 1999 'Tyrannies of Indifference: feminist and political geographies' presentation to the American Association of Geographers Annual Conference, Honolulu, Hawaii, March (mimeo)

STASIUUS, D. K. 1999 'Relational positionalities of nationalisms, racisms, and feminisms' in Between Woman and Nation: Nationalisms, Transnational Feminisms, and the State, eds. C. Kaplan, N. Alarcón, and M. Moallem (Durham: Duke University Press) 182-218

TAYLOR, C. 1999 'Two theories of modernity' Public Culture 11, 153-174 